\title{
Environmental Impact of Trawling on the Continental Shelf of Bay of Bengal
}

\author{
Dr. Mahua Das, M.Sc., Ph.D. \\ Associate Professor, UGC Postdoctoral Research Awardee, 2012-2014 \\ The Bhawanipur Education Society College (under University of Calcutta) \\ 26,Harisava Street, Khidderpore, Kolkata : 700023 \\ West Bengal, India
}

\begin{abstract}
:
Entire West Bengal offshore and estuaries situated on the Indian continental shelf along Bay of Bengal exhibits excellent breeding ground of uncountable marine species presenting the great marine ecosystem shared by World's largest mangrove food web famously 'Sundarbans' (World Heritage Site, 1989). This paper intensively studied Shankarpur-Digha fishing zone encouraged modern bull trawlers to drag bigger trawl nets through ocean bottom for huge commercial catch. This non-selective fishing gear is very likely to have destroyed undersea habitat of uncountable benthic species which actually form extensively broad baseline of complex marine food chain. If any baseline component is found damaged by anthropogenic intervention, entire marine food pyramid must be collapsed posing threat to all top consumers. Trawling is proved to destroy huge non-economic but ecologically worthy marine juveniles occupied primary and secondary trophic levels, creating great food crisis for all predators whose sustenance is suspected to be at stake. Resultantly the apex species are also bound to face food crisis, ultimately leaving whole seafood- dependent coastal fisherfolk the worst sufferer. Benthic nutrients deposition and growth is proved getting thinner with increasing offshore distance and depth showing higher biodiversity loss by trawling near the coast. Unfortunately, most trawlers in West Bengal offshore practice fishing in biodiversity-enriched shallower water to ensure highest catch with maximum profit damaging the submarine ecosystem maximum. This study statistically quantified trawl induced biodiversity loss along with chemical disturbances in submarine soil and water and suggested effective Environmental Management Plan to ensure conservative use of marine resources for a sustainable marine ecosystem not only in West Bengal offshore but also applicable to all tropical trawling grounds of the world.
\end{abstract}

Keywords: Offshore ecosystem in West Bengal; Largest mangrove food web; Commercial trawl netting; Affected benthic environment; Sustainable development.

\subsection{Introduction}

Entire coastal and estuarine area of West Bengal in India exhibits excellent breeding ground of uncountable marine species presenting the great marine ecosystem also with the world's largest mangrove food web famous as 'Sundarbans' (World Heritage Site, 1989). Increasing population and higher demand for fish has made trawl netting intensified in West Bengal offshore since the last decade. As a non-selective fishing gear dragged through ocean bottom modern bull trawlers are very likely to have destroyed uncountable benthic species and their undersea habitat, which actually form the extensive baseline of the complex marine food chain as well as mangrove food web. To reveal the destructive trawling impact, this paper presents an intensive field-study of West Bengal offshore trawl fishing zones that remains totally unrevealed and deserves extra attention for intrinsic national and international value of the largest mangrove ecosystem in Sundarbans (World Heritage Site). The objective behind this study is to determine trawl induced benthic biological and chemical disturbances and to chalk out environmental management plan for a sustainable marine environment. As methodology, experimental sampling of benthic fauna at different offshore locations and depth, identification of species and discards analysis, testing of physico-chemical parameters of sea water and benthic soil were completed to assess trawl induced biological and chemical disturbances on marine food chain. Finally, the outcome of the project surely helped undertake a proper Ocean Environment Management Plan suggesting the best conservative use of tropical marine biodiversity for sustainable development.

\subsection{Materials and Methods :}

\subsection{Area studied :}

Entire Bay of Bengal offshore on the south of the State of West Bengal in India enjoys many commercial fishing zones of which Shankarpur and Digha, the present study areas are demarcated by State of West Bengal on the North, Bay of Bengal on the South, Bangladesh on the East and State of Orissa on the West (Map no. 1). All modern bull trawlers usually start their trip from Digha and Shankarpur round the year only excluding $2-3$ months of pre-monsoon or summer. 


\subsection{Ecological importance of West Bengal offshore :}

In the unique bio-climatic littoral and infra-littoral zone of West Bengal, estuarine \& marine ecosystem including Sundarban's mangrove food web (Diag.1) exists with huge reserve of microscopic phyto-planktons forming the extensively broad baseline of marine food chain and mangrove food web as well, followed by other marine species occupying different higher trophic levels. It is well understood that if any of these baseline components is found missing or damaged by any sort of human intervention, entire marine food pyramid must be collapsed in long run and pose a great threat to all top consumers (Das.M, 2002). Large number of modern bull trawlers engaged in commercial fishing use to drag bigger trawl nets through ocean-bottom while chasing bottom-dweller target species of fish (Diag.2a). As a mobile non-selective fishing gear, the bottom trawl net (Diag.2b) collects every organism in its path and the incidental capture of non-target species - by-catch - has become a major concern allied to trawling (Kumar, A. B. and Deepthi, G. R, 2006). This dragging action is very likely to have destroyed under-sea habitat of huge quantity of benthic and non-benthic species playing essential role as the primary and secondary consumers in the marine food-chain as well as Mangrove Food Web. This malpractice through years seems to have shortened the broad base of marine food pyramid supplying much lesser amount of energy accordingly to the tertiary and top consumers (Das.M, 2010). As an outcome, this will pose a great threat to the sustenance of all dependant marine species occupying higher trophic levels. Ultimately, this will endanger the existence of the coastal humans too as the apex species of the food pyramid. Because the coastal fisherfolk is absolutely dependent on marine stuffs for their major food supply and consider fishing as their primary occupation. Even if this malpractice is left untreated through years, vast global tropic marine ecosystem will start affected in long run.

\subsection{Objectives :}

Objective of this study is 1) to determine the quantity of discards which otherwise form the non-target group and assess the loss of biodiversity with distance and depth of trawling, 2) to study the impact of biodiversity loss on the marine food chain 3) to determine seasonal chemical changes in benthic environment and trace out trawl induced chemical disturbances and 4) to chalk out an environmental management plan ensuring sustainable marine environment.

\subsection{Methodology :}

To fulfill the specific objectives, methodological steps were followed :

a)Experimental sampling of benthic fauna was done in eight survey trips by commercial trawlers named Maa Damayanti, Safina Baija, Bijli 2, Maa Ganga, FB Ganga, FB Alakananda, Ma Bhabatarini and FB Joy Ma Padmabati at Shankarpur-Digha fishing zone on 2.02.2010, 24.02.2010, 28.01.2011, 9.02.2011, 19.12.12, $11.01 .13,8.02 .13$ and 12.2.13. at different offshore locations with varying depth. In first marine cruise $30 \mathrm{~kg}$ of discards out of $90 \mathrm{~kg}$ (total catch), in second $15 \mathrm{~kg}$ of discards out of $70 \mathrm{~kg}$ (total catch), in third $7 \mathrm{~kg}$ of discards out of $12 \mathrm{~kg}$ (total catch), in fourth $6 \mathrm{~kg}$ of discards out of $40 \mathrm{~kg}$ ( total catch), in fifth $5 \mathrm{~kg}$ of discards out of 8 $\mathrm{kg}$ (total catch), in sixth $118 \mathrm{~kg}$ of discards(115 kg for dry-fishing) out of $125 \mathrm{~kg}$ (total catch), in seventh $140 \mathrm{~kg}$ of discards (138 kg for dry-fishing)out of $150 \mathrm{~kg}$ ( total catch) (Diag.3a) and in eighth marine cruise only $10 \mathrm{~kg}$ of discards out of $50 \mathrm{~kg}$ of total catch was collected.

b) All collected discarded species are identified and analysed by Zoological Survey of India, Kolkata and S.D Marine Biological Research Institute, Sagar Island, India.

c) Loss of discards has been graphically plotted with trawling distance and depth. Based on this, a detailed statistical assessment of the impact of biodiversity loss on the marine food chain has been completed.

d) Laboratory analysis of some physico-chemical parameters was completed on the samples of benthic soil and sea water collected during trawl cruises. Soil parameters i.e, texture, organic carbon, salinity, lead, cadmium and copper and sea water parameters i,e. salinity, $\mathrm{pH}$, lead, cadmium and copper were tested in the laboratory of Envirocheck, Kolkata, India. These data has been graphically plotted in relation to 'depth', 'distance' 'time' and 'seasons' and analysed the suitability of marine environment for biodiversity growth as well as trawl induced chemical disturbances deterring the growth.

e) Environmental Management Plan has been drafted suggesting some essential remedial steps towards conservative use of these marine resources.

\subsection{Results}

\subsection{Discards identified :}

First trawler received $90 \mathrm{~kg}$ of catch including discards of about $30 \mathrm{~kg}$. Second trawler caught $70 \mathrm{~kg}$ including discards constituted $15 \mathrm{~kg}$. Total catch by third trawler was $12 \mathrm{~kg}$ with discards about $7 \mathrm{~kg}$. Fourth trawler had $40 \mathrm{~kg}$ of total catch with discards about $6 \mathrm{~kg}$. All varieties of these destroyed discards or non-target species were collected as samples and identified by Zoological Survey of India and S.D Marine Biological Research Institute, Sagar Island, India. First cruise destroyed non-target species like sting ray(Himantura imbricata), catfish, flatfish 
(flounders and soles i,e. Solea ovata), silver belly, clupid fish, gastropod(Babylonia spirata), sepia(two species, i,e. Sepia scubata and Sepia inermis), loligo(two species, i,e., Loligo sp. and Loliolus investigatoris), mud octopus(Octopus macropus), nudibranch, sea urchin(Temnopleurus toreumaticus), sea anemone, squilla(mantis shrimp) and portunus crab. Second, third and fourth cruises destroyed sting ray(Himantura imbricata), catfish, flatfish (flounders and soles i,e. Solea ovata), clupid fish, sepia(two species, i,e Sepia scubata and Sepia inermis), loligo (two species, i,e., Loligo sp. and Loliolus investigatoris), sea anemone, squilla (mantis shrimp) shark, skate(Raja.sp), halibut(Psettodes erumei) a precious commercial fish in West Bengal coast, benthic crab(Doclea ovis) very uncommon in this coast, gobid fish or mud skipper(Parachaeturichthys polynema), and squids(Loligo sp.). Fifth, sixth, seventh and eight cruises destroyed cattle fish, sting ray (Himantura imbricata), catfish, flatfish (halibut and Silago sihama), silver belly, clupid fish, sepia (two species i,e Sepia scubata and Sepia inermis), loligo (two species i,e., Loligo sp. and Loliolus investigatoris), anchovy (Coilla dussumieri), gobid fish, sea anemone, squilla (mantis shrimp) and crab (three species i.e, Matuta plenipes, Matuta victor and Charybdis feriatus). Diag.3a shows some of the identified discards specially noted for their high ecological significance and important role played in Sundarbans mangrove food-web as well as in the greater marine ecosystem.

\subsection{Chemical analysis :}

Table $1 \&$ Table 2 contain the detailed reports on the chemical analysis of all collected samples of marine water and benthic soil from different trawl cruises. These data has been graphically plotted in Fig. 2 and 3 depicting benthic soil salinity and sea water salinity, in Fig.4 and 5 depicting presence of organic carbon and sand, silt and clay in benthic soil and in Fig.6 depicting presence of lead, cadmium and copper in benthic soil. Statistical analysis shows implicative seasonal changes in the chemical composition of benthic soil and sea water that highly influences the offshore marine ecosystem in West Bengal. Trawling has also added some more effective negative chemical changes to this marine scenario discussed subsequently. A glimpse of heavy metal pollution in the benthic soil for which trawl is partially responsible is also recorded here in Fig.6.

\subsection{Discussion :}

Increasing contribution of trawlers to the total catch of fish observed in the coastal West Bengal during the last few decades clearly indicates much more severe related destruction of the habitats of bottom dweller juvenile species because of the non-floating rather dragging device of trawl. A single passage of beam trawl has been reported to kill $5-65 \%$ of the resident fauna and mix the top few centimeters of sediment (Duplisea et al). The non-target species may have key roles in the marine food-webs that fortify ecosystem processes and functioning, which in turn determines the productivity of marine capture fisheries (Auster, P. J. and Langton, R. W). Habitat impacts and by-catches affect stocks of commercially valuable species, the natural biodiversity and ecological services provided (McAllister, D. E. and Spiller, G.) .Large number of non-target species are caught as by-catch during netting as a result of the non-selective nature of bottom trawl net. These non-economic but ecologically important species occupy specific positions at different trophic levels of the marine food chain. Loss of these species has obviously damaged the existence of their predators occupying all the higher trophic levels. Diag. 3b has shown how the extensive trawl routes have already scooped out the benthic biodiversity at Lousiana. This anthropogenic malpractice seems to have already shortened the extensively broad baseline of marine food chain as well as mangrove food web existing in coastal West Bengal. This is causing supply of much lesser than necessary amount of food energy to all the higher order marine species and endangering their lives for future. It is gradually leading towards an irreparable loss not only to entire marine ecosystem but also a great threat to all dependent coastal inhabitants as the top consumers in this marine food chain.

\subsection{Statistical Assessment of the trawling impact :}

4.1.1 Assessment of the marine biological impact :

Marine biodiversity loss is recorded as the most severe impact of commercial trawl fishing. In first marine cruise, $33.33 \%$ (approx) discards was destroyed from 35 feet out of 2.6 miles ( 7.4 to 10 miles) of trawling from Shankarpur. In second marine cruise, $21.42 \%$ (approx) discards was destroyed from 38 feet out of 1.5 miles (6 to 8.5 miles) of trawling from Digha. Comparing two results, richness of benthic biodiversity is proved higher (loss of $21.42 \%$ ) on the continental shelf closer to the coast off Digha and much lesser (loss of 19.23\%) on the continental shelf far from the coast off Shankarpur. Benthic biodiversity higher near coast thinning away from the coast has proved biodiversity richness inversely related to the offshore distance. Bio-geographically, huge nutrients continuously washed off the land by numerous rivers of Bhagirathi-Hooghly delta to be thickly deposited onto the continental shelf of Bay of Bengal gets thinner away from the coast. Moreover, Trawl depth of continuous 35 feet off Shankarpur has proved a shallower continental shelf with natural ecological viability for richer benthic biodiversity. In contrast, increasing trawl depth of 29 to 38 feet off Digha has proved more gradient continental shelf with natural possibility of supporting lesser benthic biodiversity. But study has proved lesser biodiversity loss (19.23\%) in Shankarpur offshore than that $(21.42 \%)$ in Digha despite more ecologically 
viable continental shelf. Though more gradient than that of Shankarpur, Digha offshore enjoys higher nutrient deposition and higher biodiversity loss as it is about1.5 miles closer to the coast than Shankarpur. It has proved benthic nutrients deposition as well as growth of biodiversity getting thinner with increasing offshore distance, Comparing third and fourth cruises, 58.33\% loss of benthic biodiversity at 20.5 feet between 3 and 3.7 miles is much higher than $15 \%$ loss of benthic biodiversity at 47 to 50.6 feet between 6.72 and $9.47 \mathrm{~km}$ in the same offshore. It corroborates that higher loss of benthic biodiversity at shallower continental shelf closer to the coast because of maximum benthic nutrient deposition at near coast submarine zone and vice versa. Fifth cruise proves that $62.5 \%$ discards was destroyed from 35 feet out of $0.5 \mathrm{~km}$ of trawling at Shankarpur offshore. Sixth marine cruise caught $94.4 \%$ loss of biodiversity (2.4\% absolute discards and $92 \%$ for dry-fishing) from 26.3 feet out of 5 $\mathrm{km}$ of trawling from Digha. Seventh cruise shows $98.7 \%$ loss of benthic biodiversity $(6.7 \%$ absolute discards and $92 \%$ discards for dry fish) at 28.2 feet out of $3.17 \mathrm{~km}$ of trawling off Digha. Eighth cruise recorded $20 \%$ loss of benthic biodiversity at 34.6 feet out of $3 \mathrm{~km}$ of trawling off Shankarpur. Comparing the results of fifth and eighth marine cruises held at Shankarpur offshore, loss of marine biodiversity is recorded at higher rate $(62.5 \%)$ in near offshore $(2.5 \mathrm{~km}-3.00 \mathrm{~km})$ whereas much lower $(20 \%)$ in far offshore. Moreover, Digha offshore is proved as much shallower $(26.3$ feet at $14 \mathrm{~km}$ and 28.2 feet at $16.0 \mathrm{~km})$ with higher loss of benthic biodiversity $(94.4 \%$ and 98.7\%). But Shankarpur offshore is found steeper ( 35 feet at $3 \mathrm{~km}$ and 34.6 feet at $15 \mathrm{~km}$ ) with lesser loss of benthic biodiversity $(62.5 \%$ and $20 \%)$. It has proved higher loss of benthic biodiversity at shallower continental shelf closer to the coast because of more benthic nutrient deposition here. Table 1,Table 2 and Fig. 1 shows the loss of marine biodiversity in relation to the 'depth of trawling' and 'starting distance of trawling'. This too proves that trawling at higher depth as well as far from the coast causes lesser marine biodiversity loss than that performed in shallow water at lower depth near the coast. Unfortunately, most of the commercial trawlers in West Bengal offshore practice fishing invariably in the biodiversity-enriched shallower water closer to the coast to ensure highest catch with maximum profit at the cost of maximum damage to submarine ecosystem.

\subsubsection{Damage to the global marine ecosystem :}

This malpractice ultimately causes an irreparable loss not only to the Sundarbans mangrove food web existing in the Indian offshore. But the entire tropical oceanic food chain is going to be affected in long run and ultimately the worldwide marine ecosystem will also feel shortfall due to the absence of these base level marine species. Immediate biological damages caused by trawling action are as follows :

a) Loss of sea anemons and sea urchins must put their predators i.e, sea snails, sea spiders, grey sea slugs, sea stars and large demarsal fishes into crisis of survival, b) destruction of sepia and loligo creates severe food crisis for commercial fish species, cuttlefish, pelagic finfish, ocean pike, sting ray, eel, dolphin, seal, marine (diving) birds, c) skates are also destroyed putting their predators i.e, shark and sting rays in danger, d) Regular loss of shark, sepia, loligo, flat fish (flounders and soles), squilla and halibut as indispensable food is ultimately causing food crisis for coastal population as the top consumers of marine food chain, e) destruction of cuttlefish as major food for dolphins, sharks, seals causes crisis of their survival, f) flatfishes (Sillago sihama, Cinoglosus sp.) and anchovy (Coila dussumieri) destroyed largely by trawling create lack of food for bony-fishes and fin fishes, g) marine benthic crabs namely Matuta plenipes and Matuta victor are totally destroyed putting flatfishes in danger as their important food, h) Destruction of benthic crabs namely Charybdis feriatus and C.variegata create food crisis for finfish and bony-fishes, i) destruction of eel i.e, Uroconger lepturus creates food crisis for bass, lake trouts, fish-eating birds and marine mammals. j) at random destruction of grooved rajor fish (Centriscus scutatus) puts seals in food crisis. Commercial trawling is therefore proved to cause not only short term or ready loss to the immediately upper trophic level species affecting only the local mangrove ecosystem in West Bengal offshore. But this malpractice also has a far-reaching impact to cause ultimate long term loss to all the higher order marine species dominating the greater global oceans. Even the large sea-food dependant tropical coastal population of Asia, South-East Asia, Oceania and Polynesia will also be at stake as the apex omnivores in the greater marine food chain. As all the oceanic ecosystems are ecologically interconnected, great global marine ecosystem must also be affected in common by such a malpractice. Thus this apparently localized trawl induced malpractice will very soon take shape of a global marine environmental disaster in near future. If this anthropogenic interference is left untreated for years, global marine ecosystem will start collapsing in long run. Thus trawl-based economic development in coastal West Bengal is gained at the cost of great ecological loss to the international coastal and marine environment.

\subsubsection{Assessment of the marine chemical impact :}

Next alarming impact of trawling found is marine chemical changes. According to the chemical analysis of benthic soil (Table.5 \& Fig.2), decreasing percentage of sand with increasing silt and clay towards the land in shallower continental slope proves the presence of very nutritious submarine bed formed of thick deposition of fresh silt by various distributaries of river Hooghly near the estuarine mouth supporting rich growth of benthic biodiversity in entire Bay of Bengal offshore. Sand increases obviously with decreasing silt \& clay away from the land in deeper sea slope. As a support to this fact, organic carbon $(\mathrm{gm} / \mathrm{kg})$ in the benthic soil is also found decreasing away from the land in deeper sea slope with an increase landward in shallower benthic zone (Table 6 
\& Fig 3). Moreover, Electrical conductivity or salinity of the benthic soil (Table $7 \&$ Fig 4 ) and total phosphate (Table 1) are also found increasing landward with a decrease away from the land. Salinity of sea water (Table 8 \& Fig 5) interestingly shows a marked relation with daily tidal times and also with change of seasons. After the end of monsoonal rain sea water salinity starts increasing slowly during winter period and attains maximum uprising during entire pre-monsoon till the on break of next monsoon. All these physico-chemical parameters recorded in the benthic soil as well as sea water all along the trawl survey routes have together contributed to highly rich growth of benthic biodiversity all along the broad continental shelf area adjacent to the deltaic West Bengal. So a huge loss of benthic biodiversity can be easily assumed due to continuous commercial trawl netting in this offshore zone that needs to be immediately taken care of.

\subsubsection{Damage to the marine chemical environment :}

Trawling as an extreme bioturbator highly affects undersea sediment function, carbon mineralization and biogeochemical cycles. The macro-benthos of the sea bottom are important carbon consumers and their presence reduces the magnitude of available fluxes. Model studies by Duplisea et al. showed that in soft sediment systems, where the level of physical disturbance due to waves and tides is low, intensive trawling disturbance could cause large fluctuations in benthic chemical fluxes and storage (Duplisea et al.). The dragging of trawl nets may decrease dissolved oxygen, which may be due to the mixing of reduced products such as methane and hydrogen sulphide or the re-suspended bacteria attached to sediments exerting an increase in oxygen demand in the water column (Riemann, B. and Hoffman, E). Formation of sediment clouds in the sea bottom may affect natural balance between physico-chemical parameters in the ocean, further depleting the availability of oxygen (Main, J. and Sanger, G. I.). Trawling was also found to flush out nutrients and contaminants (Messiah, et al.) and there are possibilities of rise in lethal gases such as ammonia, methane and hydrogen sulphide, affecting the life of organisms in water (Churchill, et al.). As a leading busy industrial zone of India 'Hooghly Industrial Belt' occupies both sides of the river Hooghly, it's estuarine mouth covering entire West Bengal offshore is subjected to heavy chemical pollution. The most crowded city of Kolkata is also very close to this coastal belt draining out huge effluents into the ocean through this estuarine mouth polluting entire West Bengal offshore. But continuous oil spilling and lethal water washed out of huge number of mechanized diesel operated trawlers are also additionally responsible for severe marine water and benthic soil pollution in this offshore. None of these trawlers rather mechanized boats have marine pollution control measures. Many of these do not have authentic registration obtained from the Government. As per the composition of ejection of huge toxic effluents lead, cadmium and copper are considered the most lethal benthic soil and water polluting agents having a profound impact on the coastal and marine ecosystem. Table 9 and Fig. 6 show a glimpse of benthic soil pollution in West Bengal offshore and estuarine area and seasonal changes in three parameters i.e, lead, cadmium and copper recorded along the eight trawl survey routes. As monsoonal rain dilutes down the degree of lethality, percentage of lead and copper shows a marked increase during post-monsoon or winter and becomes higher during permonsoon or summer till the onset of the next monsoon shower.

\subsection{Remedial measures :}

Intensive field survey into West Bengal offshore has revealed a profound negative impact of random destruction of non-target species on the littoral and infra-littoral habitat ecology. It proved how an apparently local marine environmental hazard is getting a big global concern day by day. Here lies the urgent need for a proper Environmental Management Plan (E.M.P) in order to ensure scientific pattern of commercial fish collection so that marine ecology will neither be polluted nor destroyed but utilised conservatively. An effective oceanic management system should be incorporated in this problem-stricken offshore area where E.M.P (Diag.4) must highlight the following checks on trawling : a) Preventive measures : i) trawl netting must be strictly banned and legal penalty should be imposed in case of violation of order, ii) night trawl should specifically be banned forever as it is the resting period of fish naturally increases the percentage of damage of non-target species, iii) monsoon trawl should also be banned forever as the spawning and maturity period for larvae and their juveniles before being caught during the next fishing season, iv) trammel nets must be introduced instead of trawl. Because trawl as a dragging device destroy benthic habitats on sea-floor. But trammel as a floating gear floats just above sea-floor to catch fish without damaging the benthic species and their undersea habitats. b) Curative measures : i) free of cost training on scientific fish collection techniques is essential for the local fishermen. They must be trained in restoring caught non-target species alive in specific containers on boat during commercial catch and releasing those all instantly into the ocean, ii) strict rules on 'on boat restoration of caught non-target species alive and instant release those into ocean' must be imposed on all trawlers and related fishermen working in West Bengal offshore, iii) village administrative They will monitor scientific operation of existing trawlers to restore non-target species and also stop further registration of new trawlers in all fishing zones off West Bengal.

\subsection{Conclusion}

To get rid of this situation, conservative use of marine resources is the only solve left. Severe intensity of trawl 
netting on marine biodiversity has been analysed here which is essential not only in West Bengal offshore but also in the entire tropical pacific featuring the dominance of commercial trawl. This is the most needful before implementing the conservative measures of marine resources in this area. This study has also suggested some necessary conservative measures application of those would certainly be effective to attain sustainable development of the marine ecosystem of Bay of Bengal and in the wider spectrum, the great tropical marine ecosystem. Here lies the relevance of this work to the present day need of satisfying both the marine fishery based economy as well as marine ecological restoration.

\section{References :}

Auster, P. J. and Langton, R. W., The effects of fishing gear on fish habitat. Am. Fish. Soc. Symp., 1999, 22, $150-187$.

Churchill J. H, Biscaye, P. E and Aikman, I. F., The character and motion of suspended particulate matter over the shelf edge and upper slope off Cape Cod, Cont. Shelf Res., 1998, 18, 789-809.

Das, M. 2002. An appraisal of aquatic resources for sustainable development in Sundarbans, Ph.D thesis, University of Calcutta, W.B, India.

Das, M. 2010, Destruction of spawns damaging mangrove ecosystem in coastal

Sundarbans, Int. J. Env. Sc, vol.1, $3^{\text {rd }}$ issue, pp. 259- 268, India.

Duplisea, D. E., Jennings, S., Malcolm, S. J., Parker, R. and Sivyer, D. B., Modelling potential impacts of bottom trawl fisheries on the soft sediment biogeochemistry in the North Sea. Geochem. Trans., 2001, $2,24-28$.

Kumar, A. Biju and Deepthi G. R, 10 April, 2006, Trawling and by-catch: Implications on marine ecosystem, Current Science, Vol. 90, No. 7.

McAllister, D. E and Spiller, G, Trawling and dredging impacts on fish habitat and by catch, Coastal Zone Canada 94, Cooperation In The Coastal Zone Conference Proceedings (eds Wells, P. G. and Ricketts, P. J.), NS Canada Coastal Zone Canada Association, Dartmouth, 1994, vol. 4, pp. 1709-1718.

Protect Sundarbans, 1994, Sundarban Biosphere Reserve, Dept. of Forest, West Bengal, India.

Riemann, B. and Hoffman, E., Ecological consequences of dredging and bottom trawling in the Limfjord, Denmark. Mar. Ecol. Prog. Ser., 1991, 69, 171-178

Main, J. and Sanger, G. I., An assessment of the scale of damage to and survival rates of young gadoid fish escaping from the cod end of a demersal trawl. Scottish Fisheries Res. Rep, 1990, 46, p.

Messiah, S. N., Rowell, T. W, Peer, D. L. and Cranford, P. J., The effects of trawling, dredging and ocean dumping on the eastern Canadian continental shelf seabed. Cont. Shelf Res., 1991, 11, 1237-1263.

Watling, L. and Norse, E. A., Disturbance of the seabed by mobile fishing gear : A comparison to forest clear cutting. Conserv. Biol., 1998, 12, 1180-1197.

Bibliography :

Bhaumik,U. et al., 2004, Fish \& Shell seed potentials in the estuaries of Sundarbans, W.B, Environ \& Ecology.22(4),CIFRI, India. pg. 796-803.

Bhaumik.U, et al.1992, Need for conservation to protect the brackish water finfish \& shellfish seed resources in Sundarbans, Enviro.\& Ecol.10(4), CIFRI, India. pg. 919-922.

Bhaumik,U. et al.,1993, Scenario of brackish water finfish \& shellfish collection in Sundarbans, J. Inland Fish. Soc. of India, 25(1),IFSI. pg. 45-50.

C.J. Smitha, H. Rumohrb, I. Karakassisa, K.N. Papadopouloua, 2003, Analysing the impact of bottom trawls on sedimentary sea beds with sediment profile imagery, Journal of Experimental Marine Biology and Ecology, 285-286 (2003) 479- 496

J. B. Jones, Environmental impact of trawling on the seabed: a review, 1992, New Zealand Journal of Marine and Freshwater Research, Vol. 26: 59-67 0028-8330/2601-0059 (c) The Royal Society of New Zealand.

J.G. Hiddink, S. Jennings, M.J. Kaiser, A.M. Queirós, D.E. Duplisea, and G.J. Piet, 17 February 2006, Cumulative impacts of seabed trawl disturbance on benthic biomass production and species richness in different habitats, NRC Research Press.

J. G. Hiddink, S. Jennings,2 and M. J. Kaiser, Ecosystems, 2006, Indicators of the Ecological Impact of BottomTrawl Disturbance on Seabed Communities, 9: 1190-1199 DOI: 10.1007/s10021-005-0164.

Julio Portela et al., Management Strategies to Limit the Impact of Bottom Trawling on VMEs in the High Seas of the SW Atlantic, Spanish Institute of Oceanography, TRAGSATEC,

General Secretariat of the Sea, Spain.

Philip Percival, 2004, Impact Of Trawl Fisheries On Marine Benthic Biogeochemistry, University Of Newcastle, Newcastle University Library, School of Iniarine Science and Technology, Australia. 
Tables \& Figure Captions :

Table : 1 Report of Chemical Analysis of Soil and Sea Water Samples

Table : 2 Report of Chemical Analysis of Soil and Sea Water Samples

Table : 3 Report of Chemical Analysis of Soil and Sea Water Samples

Table : 4 Seasonal marine biodiversity loss by trawling with 'distance' and 'depth' during 2010 - 2014

Table : 5 Benthic sand, silt \& clay with 'distance' \& 'depth' during $2010-2014$

Table : 6 Organic carbon in benthic soil with 'distance' \& 'depth' during 2010 - 2014

Table : 7 Seasonal changes in benthic soil salinity with 'distance' during 2010 - 2014

Table : 8 Seasonal changes in sea water salinity with 'distance' \& 'time' during 2010 - 2014

Table : 9 Benthic soil pollutants with 'distance’ \& 'depth' during 2010 - 2014

Map no. 1 - Location of coastal West Bengal

Diag. 1 - Mangrove Food Web

Diag.2a, $2 \mathrm{~b}$ - Trawl net functioning under sea.

Diag.3a - Ecologically valuable discards

Diag. $3 b$ - Louisiana_undersea trawling routes disturbed benthic biodiversity

Diag.4 - Environmental Management Plan

Fig. 1 - Seasonal marine biodiversity loss by trawling with 'distance' and 'depth', 2010 -2014.

Fig. 2 - Presence of benthic sand, silt \& clay since 2010 - 2013

Fig.3 - Presence of Organic carbon in benthic soil since 2010-2014

Fig.4- Seasonal changes in benthic soil salinity since $2010-2014$

Fig.5 - Seasonal changes in sea water salinity since $2010-2014$

Fig.6 - Presence of copper, lead \& cadmium in benthic soil since 2010 - 2013.

Table no. 1 Report of Chemical Analysis of Soil and Sea Water Samples

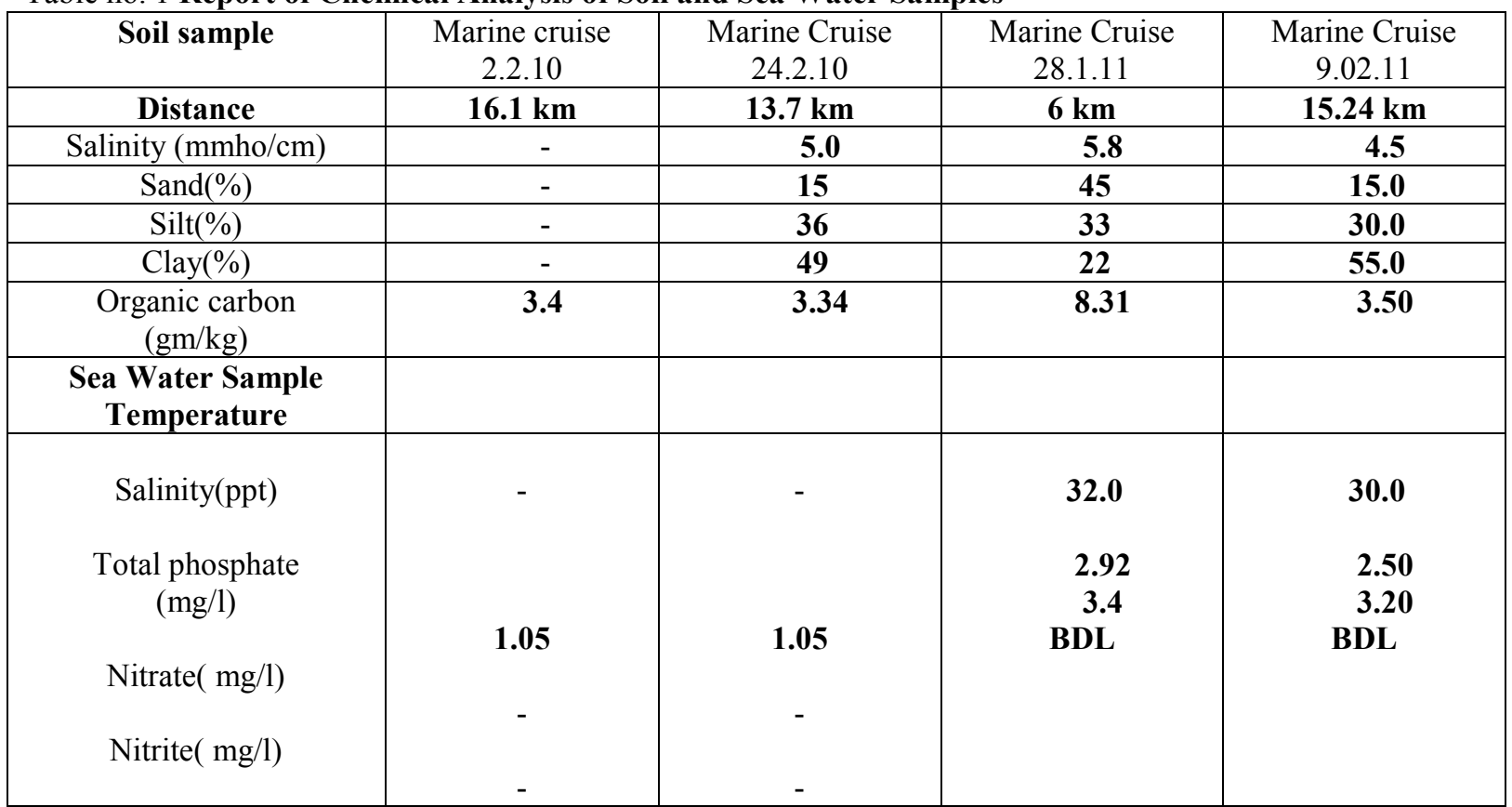

Source : Reports of chemical analysis by Envirocheck, Kolkata, India 
Table no. 2 Report of Chemical Analysis of Soil and Sea Water Samples

\begin{tabular}{|c|c|c|c|c|}
\hline Soil sample & $\begin{array}{l}\text { Marine cruise } \\
\text { on } 19.12 .2012\end{array}$ & $\begin{array}{l}\text { Marine Cruise } \\
\text { on } 11.1 .2013\end{array}$ & $\begin{array}{l}\text { Marine Cruise } \\
\text { on } 8.02 .13\end{array}$ & $\begin{array}{l}\text { Marine Cruise } \\
\text { on } 12.02 .13\end{array}$ \\
\hline Salinity(\%) & 0.4 & 0.19 & 0.21 & $4.5(\mathrm{mmho} / \mathrm{cm})$ \\
\hline Sand(\%) & 30.4 & 58.4 & 50.0 & 25.0 \\
\hline Silt(\%) & 36.0 & 16.0 & 12.0 & 28.0 \\
\hline Clay $(\%)$ & 33.6 & 25.6 & 27.6 & 52.0 \\
\hline $\begin{array}{l}\text { Organic carbon }(\%) \\
\text { Lead (ppm) } \\
\text { Cadmium (ppm) } \\
\text { Copper (ppm) }\end{array}$ & $\begin{array}{c}0.28 \\
19.5 \\
1.62 \\
19.2 \\
\end{array}$ & $\begin{array}{c}0.24 \\
16.4 \\
1.09 \\
19.05\end{array}$ & $\begin{array}{l}\mathbf{0 . 3 8 6} \\
\text { BDL } \\
\text { BDL } \\
\text { BDL }\end{array}$ & $\begin{array}{l}3.50 \mathrm{gm} / \mathrm{kg} \\
\mathbf{2 4 . 8} \\
\text { BDL } \\
\mathbf{5 0 . 9 8}\end{array}$ \\
\hline Sea Water sample & & & & \\
\hline $\begin{array}{l}\text { Temperature } \\
\text { Salinity(ppm) }\end{array}$ & $\begin{array}{c}\mathbf{2 2}^{\mathbf{0}} \mathrm{C}-\mathbf{2 3}^{\mathbf{0}} \mathrm{C} \\
\mathbf{6 5 0 0 . 0}(\text { Sample } 1) \\
\mathbf{6 0 0 0 . 0}(\text { Sample } 2)\end{array}$ & $\begin{array}{c}\mathbf{2 0}^{\mathbf{0}} \mathrm{C}-\mathbf{2 1}^{\mathbf{0}} \mathrm{C} \\
\mathbf{6 3 0 0 . 0}(\text { Sample } 1) \\
\mathbf{6 7 0 0 . 0}(\text { Sample } 2)\end{array}$ & $\begin{array}{l}21.7^{0} \mathrm{C} \\
5800.0 \\
-\end{array}$ & $\begin{array}{r}22.3^{\circ} \mathrm{C} \\
16000.0 \\
18000.0\end{array}$ \\
\hline
\end{tabular}

Table no. 3 Report of Chemical Analysis of Soil and Sea Water Samples

\begin{tabular}{|c|c|c|c|c|c|c|c|}
\hline Soil sample & $\begin{array}{c}\text { Marine } \\
\text { Cruise } \\
06.11 .13\end{array}$ & $\begin{array}{c}\text { Marine } \\
\text { Cruise } \\
07.11 .13\end{array}$ & $\begin{array}{c}\text { Marine } \\
\text { Cruise } \\
9.11 .13\end{array}$ & $\begin{array}{c}\text { Marine } \\
\text { Cruise } \\
10.11 .13\end{array}$ & $\begin{array}{c}\text { Marine } \\
\text { Cruise } \\
20.11 .13\end{array}$ & $\begin{array}{c}\text { Marine } \\
\text { Cruise } \\
09.12 .13\end{array}$ & $\begin{array}{c}\text { Marine } \\
\text { Cruise } \\
9.02 .14\end{array}$ \\
\hline Salinity(ds/m) & 3.6 & - & 12.3 & 5.2 & - & - & \\
\hline Sand(\%) & 40 & - & 42.4 & 40.1 & - & - & \\
\hline Silt(\%) & 30 & - & 27.2 & 25 & - & - & \\
\hline Clay(\%) & 30 & - & 30.4 & 34.9 & - & - & \\
\hline $\begin{array}{c}\text { Organic carbon } \\
(\mathrm{mg} / \mathrm{kg})\end{array}$ & 491.4 & 1965.6 & 2784.4 & 3030.3 & 1474.2 & 4633.2 & \\
\hline Lead (mg/kg) & 10.0 & 34.5 & 32.5 & 27.5 & 27.0 & 25.5 & \\
\hline Cadmium (mg/kg) & $\mathrm{BDL}$ & $\mathrm{BDL}$ & $\mathrm{BDL}$ & $\mathrm{BDL}$ & $\mathrm{BDL}$ & $\mathrm{BDL}$ & \\
\hline Copper (mg/kg) & 12.85 & 27.9 & 31.25 & 28.3 & 27.35 & 32.7 & \\
\hline Sea Water sample & & & & & & & \\
\hline Temperature & $29.5^{0} \mathrm{c}$ & $29.5^{\circ} \mathrm{c}$ & $29.0^{0} \mathrm{c}$ & $29.4^{0} \mathrm{c}$ & $20.4^{0} \mathrm{c}$ & $21.0^{0} \mathrm{c}$ & $22.8^{0} \mathrm{c}$ \\
\hline Salinity(ppt) & 15.0 & 16.2 & 18.8 & 18.1 & 10.0 & 8.8 & \\
\hline
\end{tabular}

Table.4 Seasonal marine biodiversity loss by trawling with 'distance' and 'depth' during 2010 - 2014

\begin{tabular}{|c|c|c|c|c|c|c|c|}
\hline $\begin{array}{l}\text { No. of } \\
\text { marine } \\
\text { cruises }\end{array}$ & Date \& season & $\begin{array}{l}\text { Starting } \\
\text { distance } \\
\text { of } \\
\text { trawling } \\
\text { (in } \mathrm{km} \text {.) }\end{array}$ & $\begin{array}{l}\text { Ending } \\
\text { distance } \\
\text { of } \\
\text { trawling } \\
\text { (in } \mathrm{km} . \text { ) }\end{array}$ & $\begin{array}{l}\text { Total } \\
\text { trawling } \\
\text { mileage } \\
\text { (in km.) }\end{array}$ & $\begin{array}{l}\text { Average } \\
\text { depth of } \\
\text { trawling } \\
\text { (in } \\
\text { meter) }\end{array}$ & $\begin{array}{l}\text { Total loss } \\
\text { of } \\
\text { biodiversity } \\
\text { (in \%) }\end{array}$ & $\begin{array}{l}\text { Loss of } \\
\text { biodiversity } \\
\text { in first } 1.5 \\
\mathrm{~km} \\
(\text { in } \%)\end{array}$ \\
\hline $1^{\text {st }}$ & 2.02.2010(Pre-monsoon) & 11.9 & 16.1 & 4.2 & 10.7 & 33.33 & 11.9 \\
\hline $2^{\text {nd }}$ & 24.02.2010(Premonsoon) & 9.7 & 13.7 & 4 & 10.2 & 21.42 & 8.03 \\
\hline $3^{\text {rd }}$ & 28.01.2011(Winter) & 4.8 & 6 & 1.2 & 6.23 & 58.33 & 72.91 \\
\hline 4th & 9.02.2011(Pre-monsoon) & 10.8 & 15.24 & 4.44 & 15 & 15 & 5.07 \\
\hline 5th & 19.12.12(Winter) & 2.5 & 3 & 0.5 & 2 & 62.5 & 62.5 \\
\hline 6th & 11.01.13(Winter) & 9 & 14 & 5 & 7.6 & 94.4 & 28.32 \\
\hline 7th & 8.02.13(Pre-monsoon) & 13 & 16.2 & 3.2 & 8.4 & 46.66 & 21.87 \\
\hline $8^{\text {th }}$ & 12.02.13(Pre-monsoon) & 12 & 15 & 3 & 9.7 & 20 & 10 \\
\hline $9^{\text {th }}$ & 6.11.13(post-monsoon) & 3.7 & 4.63 & 0.93 & 7.13 & 33.33 & 53.76 \\
\hline $10^{\text {th }}$ & 7.11 .13 (post-monsoon) & 5.56 & 6.48 & 0.92 & 6.04 & 11.11 & 18.12 \\
\hline $11^{\text {th }}$ & 9.11.13(post-monsoon) & 10 & 15 & 5 & 13.34 & 30 & 9 \\
\hline $12^{\text {th }}$ & 10.11.13(post-monsoon) & 5 & 8 & 3 & 5.05 & 16.67 & 8.34 \\
\hline $13^{\text {th }}$ & 20.11.13(winter) & 3.64 & 5 & 1.36 & 8.23 & - & - \\
\hline $14^{\text {th }}$ & 9.12.13(winter) & 3.5 & 4 & 0.5 & 7.62 & 60 & 25.71 \\
\hline $15^{\text {th }}$ & 9.02.14(pre-monsoon) & 6 & 10 & 4 & 7.62 & 66.66 & 25 \\
\hline
\end{tabular}


Table.5 Benthic sand, silt \& clay with 'distance' \& 'depth' during 2010 - 2014

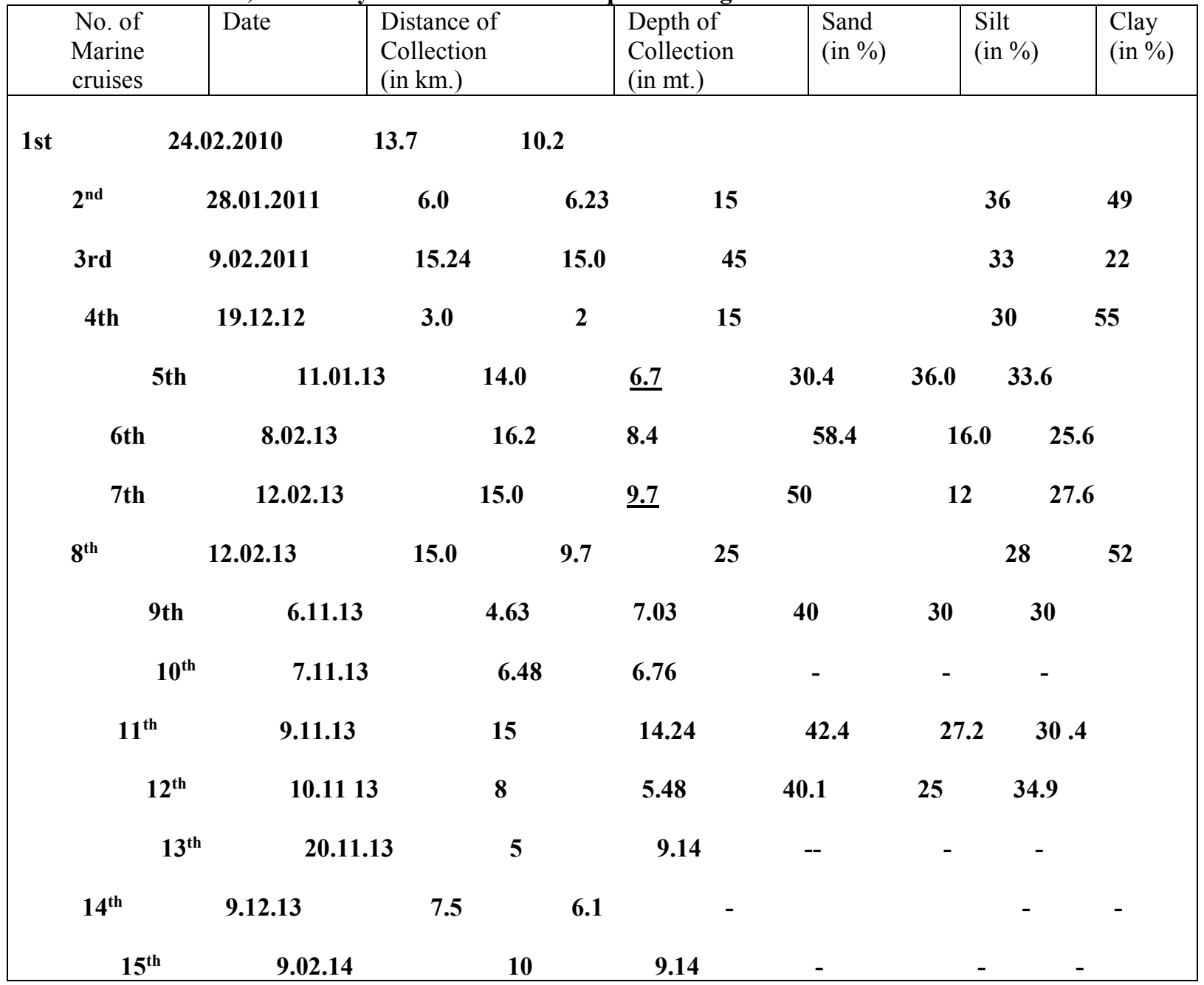

Table.6 Organic carbon in benthic soil with 'distance' \& 'depth'during 2010 - 2014

\begin{tabular}{|c|c|c|c|c|}
\hline $\begin{array}{l}\text { No. of } \\
\text { Marine } \\
\text { cruises }\end{array}$ & Date & $\begin{array}{l}\text { Distance of } \\
\text { Collection } \\
\text { (in km.) }\end{array}$ & $\begin{array}{l}\text { Depth of } \\
\text { Collection } \\
\text { (in mt.) }\end{array}$ & $\begin{array}{l}\text { Organic carbon } \\
\text { (in } \mathrm{gm} / \mathrm{kg} \text {.) }\end{array}$ \\
\hline $1^{\text {st }}$ & 2.02.2010 & 16.1 & 10.7 & 3.4 \\
\hline $2^{\text {nd }}$ & 24.02.2010 & 13.7 & 10.2 & 3.34 \\
\hline $3^{\text {rd }}$ & 28.01.2011 & 6.0 & 6.23 & 8.31 \\
\hline 4th & 9.02.2011 & 15.24 & 15.0 & 3.50 \\
\hline $5^{\text {th }}$ & 19.12.12 & 3.0 & 2 & 2.8 \\
\hline $6^{\text {th }}$ & 11.01.13 & 14.0 & 7.6 & 2.4 \\
\hline $7^{\text {th }}$ & 8.02.13 & 16.2 & 8.4 & 3.86 \\
\hline $8^{\text {th }}$ & 12.02.13 & 15.0 & 9.7 & 3.50 \\
\hline 9th & 6.11 .13 & 4.63 & 7.03 & 0.49 \\
\hline $10^{\text {th }}$ & 7.11.13 & 6.48 & 6.76 & 1.97 \\
\hline $11^{\text {th }}$ & 9.11.13 & 15 & 14.24 & 2.78 \\
\hline $12^{\text {th }}$ & 10.1113 & 8 & 5.48 & 3.03 \\
\hline $13^{\text {th }}$ & 20.11.13 & 5 & 9.14 & 1.47 \\
\hline $14^{\text {th }}$ & 9.12.13 & 7.5 & 6.1 & 4.63 \\
\hline $15^{\text {th }}$ & 9.02 .14 & 10 & 9.14 & 5.51 \\
\hline
\end{tabular}


Table.7Seasonal changes in benthic soil salinity with 'distance' \& 'depth'during 2010 - 2014

\begin{tabular}{|c|c|c|c|}
\hline $\begin{array}{l}\text { No. of } \\
\text { Marine } \\
\text { cruises }\end{array}$ & $\begin{array}{l}\text { Date } \\
\text { \& season }\end{array}$ & $\begin{array}{l}\text { Distance of } \\
\text { Collection } \\
(\text { in } \mathrm{km})\end{array}$ & $\begin{array}{l}\text { Benthic soil salinity } \\
\text { (in } \mathrm{mmho} / \mathrm{cm} \text { ) }\end{array}$ \\
\hline $1^{\text {st }}$ & $\begin{array}{l}\text { 2.02.2010 } \\
\text { Pre-monsor }\end{array}$ & 16.1 & 4.2 \\
\hline $2^{\text {nd }}$ & $\begin{array}{l}\text { 24.02.2010 } \\
\text { Pre-monsor }\end{array}$ & 13.7 & 5.0 \\
\hline $3^{\text {rd }}$ & $\begin{array}{l}\text { 28.01.2011 } \\
\text { Winter }\end{array}$ & 6 & 5.8 \\
\hline 4th & $\begin{array}{l}\text { 9.02.2011 } \\
\text { Pre-monsoc }\end{array}$ & 15.24 & 4.5 \\
\hline $5^{\text {th }}$ & $\begin{array}{l}\text { 19.12.12 } \\
\text { Winter }\end{array}$ & 3 & 4 \\
\hline $6^{\text {th }}$ & $\begin{array}{l}\text { 11.01.13 } \\
\text { Winter }\end{array}$ & 14 & 1.9 \\
\hline $7^{\text {th }}$ & $\begin{array}{l}\text { 8.02.13 } \\
\text { Pre-monsor }\end{array}$ & 16.2 & 2.1 \\
\hline $8^{\text {th }}$ & $\begin{array}{l}\text { 12.02.13 } \\
\text { Pre-monsor }\end{array}$ & 15 & 4.5 \\
\hline 9th & $\begin{array}{l}\text { 6.11.13 } \\
\text { Post-monso }\end{array}$ & 4.63 & $3.6 \mathrm{ds} / \mathrm{m}$ \\
\hline $10^{\text {th }}$ & $\begin{array}{l}\text { 7.11.13 } \\
\text { Post-monso }\end{array}$ & 6.48 & - \\
\hline $11^{\text {th }}$ & $\begin{array}{l}\text { 9.11.13 } \\
\text { Post-monso }\end{array}$ & 15 & 12.3 \\
\hline $12^{\text {th }}$ & $\begin{array}{l}\text { 10.11.13 } \\
\text { Post-mons }\end{array}$ & on & 5.2 \\
\hline $13^{\text {th }}$ & $\begin{array}{l}20.11 .13 \\
\text { Winter }\end{array}$ & 5 & - \\
\hline $14^{\text {th }}$ & $\begin{array}{l}9.12 .13 \\
\text { Winter }\end{array}$ & 7.5 & - \\
\hline $15^{\text {th }}$ & $\begin{array}{l}9.02 .14 \\
\text { Pre-monso }\end{array}$ & 10 & - \\
\hline
\end{tabular}

Table.8 Seasonal changes in sea water salinity with 'season' \& 'time' during 2010 - 2014

\begin{tabular}{|l|l|l|l|l|l|}
\hline $\begin{array}{l}\text { Cruise } \\
\text { no }\end{array}$ & Date & Season & $\begin{array}{l}\text { Temperature } \\
\left(\text { in }^{0}\right)\end{array}$ & Time & $\begin{array}{l}\text { Sea water } \\
\text { Salinity(in ppt })\end{array}$ \\
\hline 1 & $\mathbf{2 . 2 . 1 0}$ & Pre-monsoon & & & - \\
\hline 2 & $\mathbf{2 4 . 2 . 1 0}$ & Pre-monsoon & & & - \\
\hline 3 & $\mathbf{2 8 . 1 . 1 1}$ & winter & & $\mathbf{3 . . 4 5}$ & $\mathbf{3 2}$ \\
\hline 4 & $\mathbf{9 . 0 2 . 1 1}$ & Pre-monsoon & & $\mathbf{1 2 . 5 0}$ & $\mathbf{3 0}$ \\
\hline 5 & $\mathbf{1 9 . 1 2 . 1 2}$ & winter & $\mathbf{2 2}$ & $\mathbf{1 2 . 2 7}$ & $\mathbf{6 . 5}$ \\
& & & & $\mathbf{1 2 . 5 7}$ & $\mathbf{6 . 0}$ \\
\hline 6 & $\mathbf{1 1 . 1 . 1 3}$ & winter & $\mathbf{2 1}$ & $\mathbf{1 0 . 3 0}$ & $\mathbf{6 . 3}$ \\
& & & $\mathbf{1 1 . 4 8}$ & $\mathbf{6 . 7}$ \\
\hline 7 & $\mathbf{8 . 0 2 . 1 3}$ & Pre-monsoon & $\mathbf{2 1 . 7}$ & $\mathbf{8 . 4 5}$ & $\mathbf{5 . 8}$ \\
\hline 8 & $\mathbf{1 2 . 0 2 . 1 3}$ & Pre-monsoon & $\mathbf{2 . 3}$ & $\mathbf{1 0 . 4 0}$ & \\
\hline 9 & & & $\mathbf{1 1 . 2 5}$ & $\mathbf{1 6}$ \\
\hline 10 & $\mathbf{6 . 1 1 . 1 3}$ & Post-monsoon & - & $\mathbf{1 2 . 3 0}$ & $\mathbf{1 8}$ \\
\hline 11 & $\mathbf{9 . 1 1 . 1 3}$ & Post-monsoon & - & $\mathbf{1 2 . 2 0}$ & $\mathbf{1 5}$ \\
\hline 12 & $\mathbf{1 0 . 1 1 . 1 3}$ & Post-monsoon & $\mathbf{2 9 . 4}$ & $\mathbf{4 . 0 0}$ & $\mathbf{1 8 . 8}$ \\
\hline 13 & $\mathbf{2 0 . 1 1 . 1 3}$ & Post-monsoon & $\mathbf{2 3 . 5}$ & $\mathbf{4 . 0 0}$ & $\mathbf{1 8 . 1}$ \\
\hline 14 & $\mathbf{9 . 1 2 . 1 3}$ & winter & $\mathbf{1 9}$ & $\mathbf{1 2 . 5 7}$ & $\mathbf{1 0 . . 0}$ \\
\hline 15 & $\mathbf{9 . 0 2 . 1 4}$ & Pre-monsoon & $\mathbf{2 2 . 8}$ & $\mathbf{1 . 0 0}$ & $\mathbf{8 . 8}$ \\
\hline & & & $\mathbf{1 2 . 2 0}$ & $\mathbf{2 2 . 4}$ \\
\hline
\end{tabular}


Table.9 Benthic soil pollutants with 'distance' \& 'depth' during 2010 - 2014

\begin{tabular}{|c|c|c|c|c|c|c|}
\hline $\begin{array}{l}\text { No. of } \\
\text { Marine } \\
\text { cruises }\end{array}$ & \begin{tabular}{c|c} 
Date & $\mathrm{I}$ \\
\& season & \\
\end{tabular} & $\begin{array}{l}\text { Distance of } \\
\text { Collection } \\
\text { (in km.) }\end{array}$ & $\begin{array}{l}\text { Depth of } \\
\text { Collection } \\
\text { (in mt.) }\end{array}$ & $\begin{array}{c}\text { Lead } \\
\text { (in ppm) }\end{array}$ & $\begin{array}{l}\text { Cadmium } \\
\text { (in ppm) }\end{array}$ & $\begin{array}{l}\text { Copper } \\
\text { (in ppm ) }\end{array}$ \\
\hline $5^{\text {th }}$ & $\begin{array}{l}19.12 .12 \\
\text { Winter }\end{array}$ & 3.0 & 2 & 19.5 & 1.62 & 19.2 \\
\hline $6^{\text {th }}$ & $\begin{array}{l}\text { 11.01.13 } \\
\text { Winter }\end{array}$ & 14.0 & 7.6 & 16.4 & 1.09 & 19.05 \\
\hline $7^{\text {th }}$ & $\begin{array}{l}8.02 .13 \\
\text { Pre-monsoon }\end{array}$ & 16.2 & 8.4 & BDL & BDL & BDL \\
\hline $8^{\text {th }}$ & $\begin{array}{l}12.02 .13 \\
\text { Pre-monsoon }\end{array}$ & 15.0 & 9.7 & 24.8 & BDL & 50.98 \\
\hline $9^{\text {th }}$ & $\begin{array}{l}\text { 6.11.13 } \\
\text { Post-monsoon }\end{array}$ & 4.63 & 7.13 & 10.0 & BDL & 12.85 \\
\hline $10^{\text {th }}$ & $\begin{array}{l}7.11 .13 \\
\text { Post-monsoon }\end{array}$ & 6.48 & 6.76 & 34.5 & BDL & 27.9 \\
\hline $11^{\text {th }}$ & $\begin{array}{l}9.11 .13 \\
\text { Post-monsoon }\end{array}$ & 15 & 14.24 & 32.2 & BDL & 31.25 \\
\hline $12^{\text {th }}$ & $\begin{array}{l}\text { 10.11.13 } \\
\text { Post-monsoon }\end{array}$ & 5.48 & 12 & 27.5 & BDL & 28.3 \\
\hline $13^{\text {th }}$ & $\begin{array}{r}20.11 .13 \\
\text { Winter }\end{array}$ & 5 & 9.14 & 27.0 & BDL & 27.35 \\
\hline $14^{\text {th }}$ & $\begin{array}{l}9.12 .13 \\
\text { Winter }\end{array}$ & 7.5 & 6.09 & 25.5 & BDL & 32.7 \\
\hline $15^{\text {th }}$ & $\begin{array}{l}9.02 .14 \\
\text { Pre-monsoon }\end{array}$ & 10 & 9.14 & 35.1 & BDL & 32.8 \\
\hline
\end{tabular}




\section{LOCATION OF COASTAL WEST BENGAL}

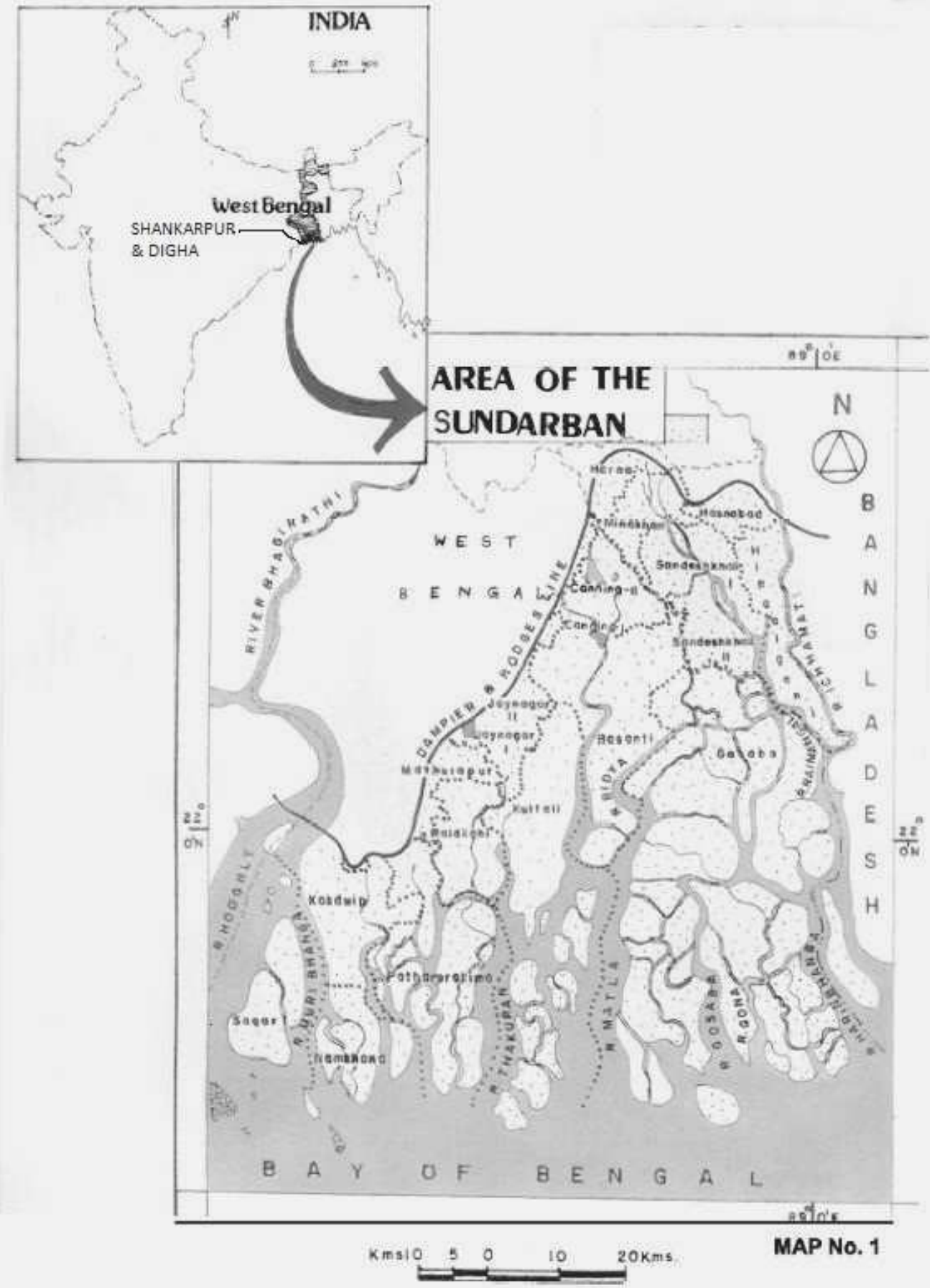

Source: NATMO, 1998, Dept. of Sc. \& Tech, Govt. of India.

$a$ 


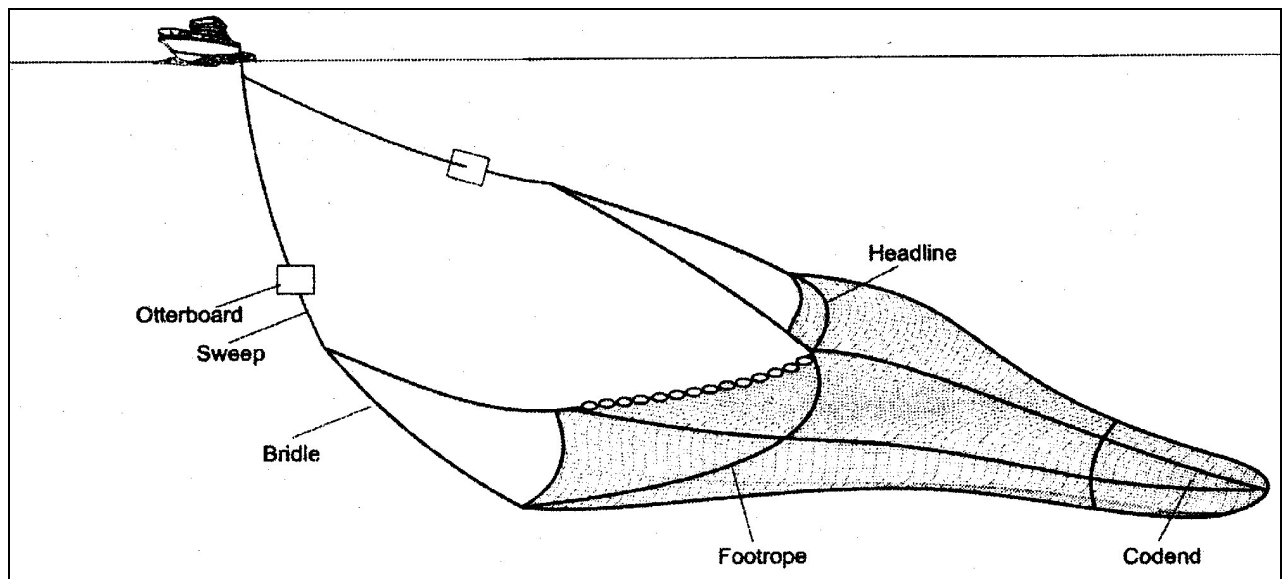

Diag.2 Trawl net functioning under sea (Current Science, Vol. 90, No. 7, 10 April 2006, Pg 922 $a$ A trawler in operation, $b$ A bottom trawl net and its parts.

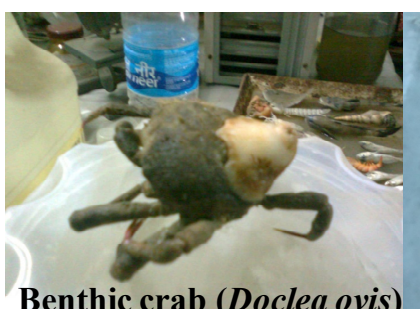

Benthic crab (Doclea ovis)

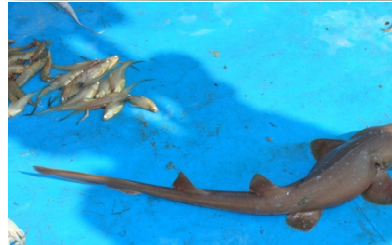

Skate (Raja. sp)

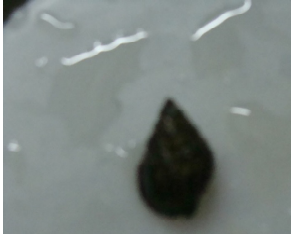

Gastropod(Nassarius

Stolatus)

Diag.3a Ecologically valuable discards
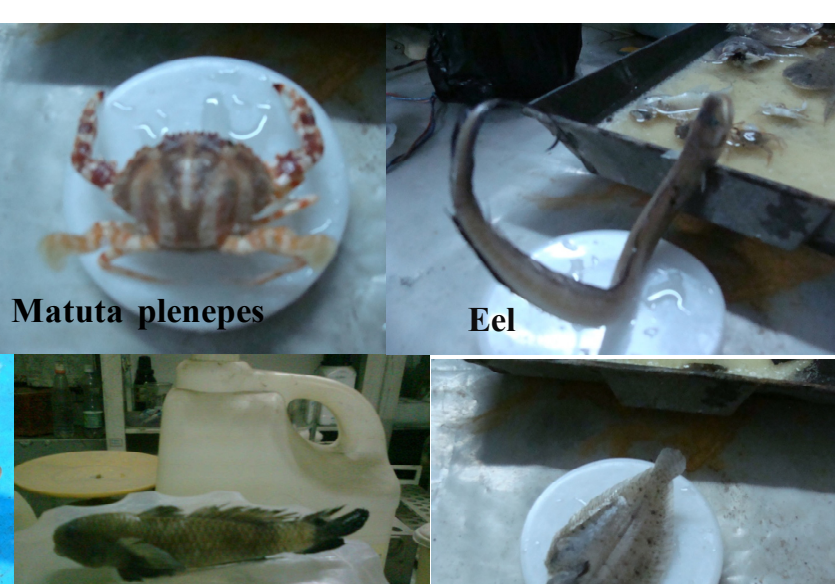

Gobid (Parachaeturichth polynema),

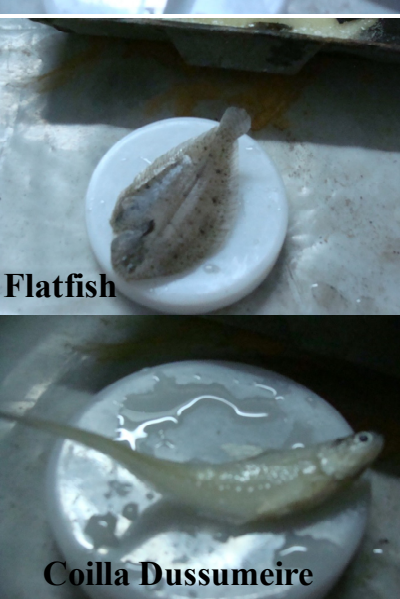




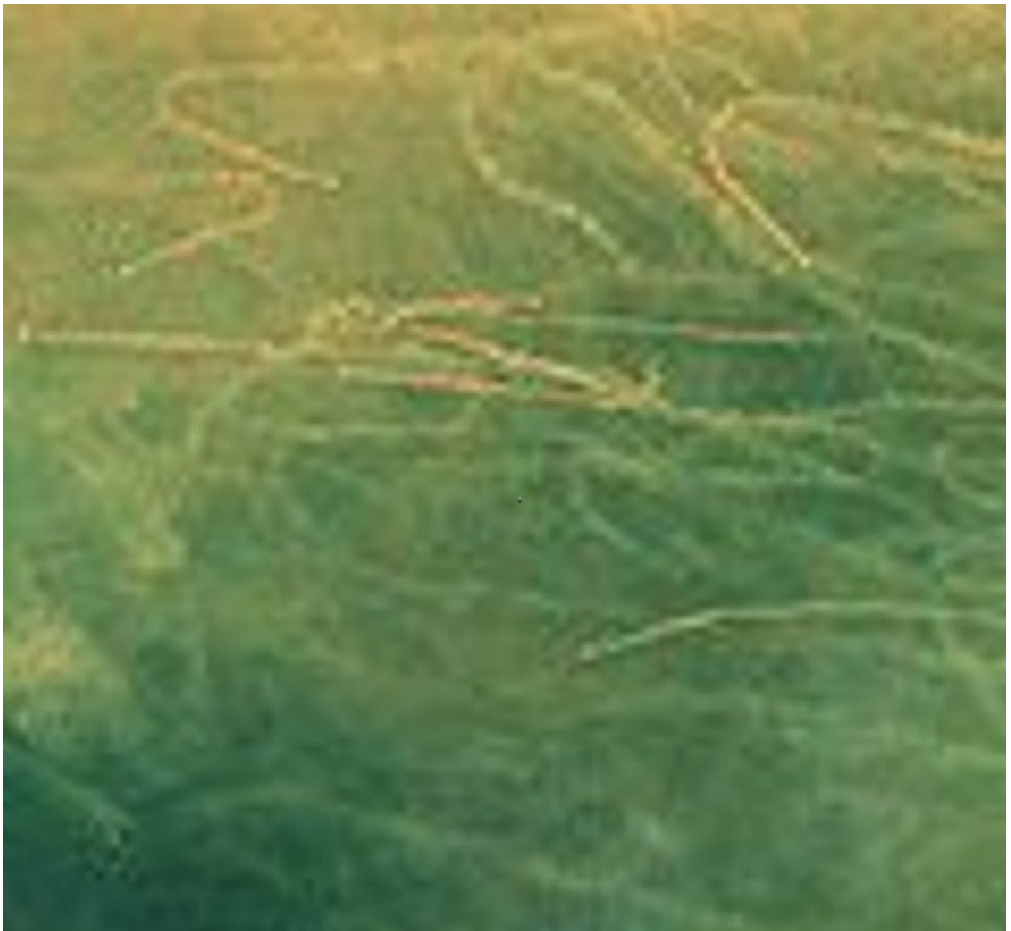

Diag. 3b Louisiana undersea trawling routes disturbed benthic biodiversity

\section{Environmental Management Plan}

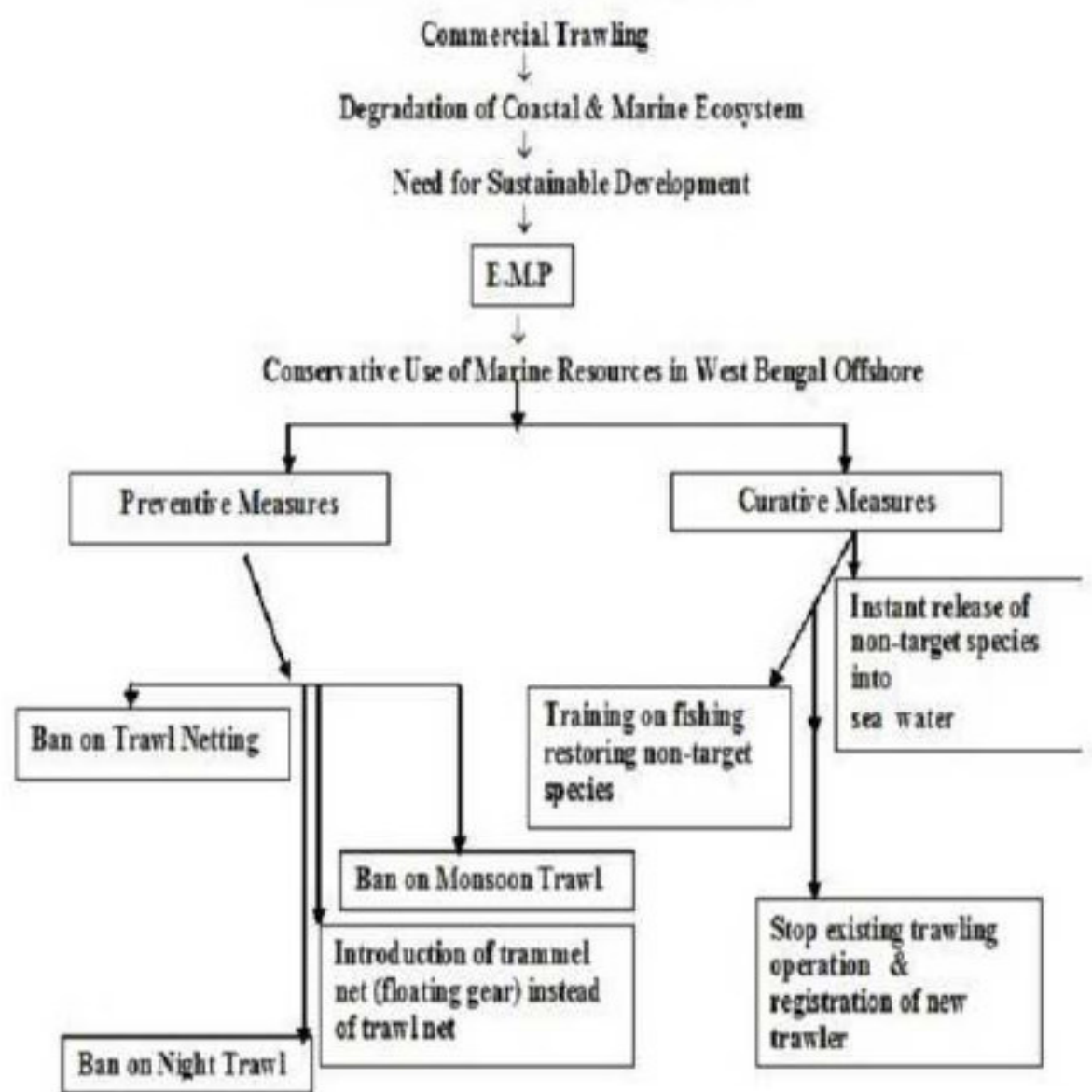

Diag 4 Environment Management Plan 


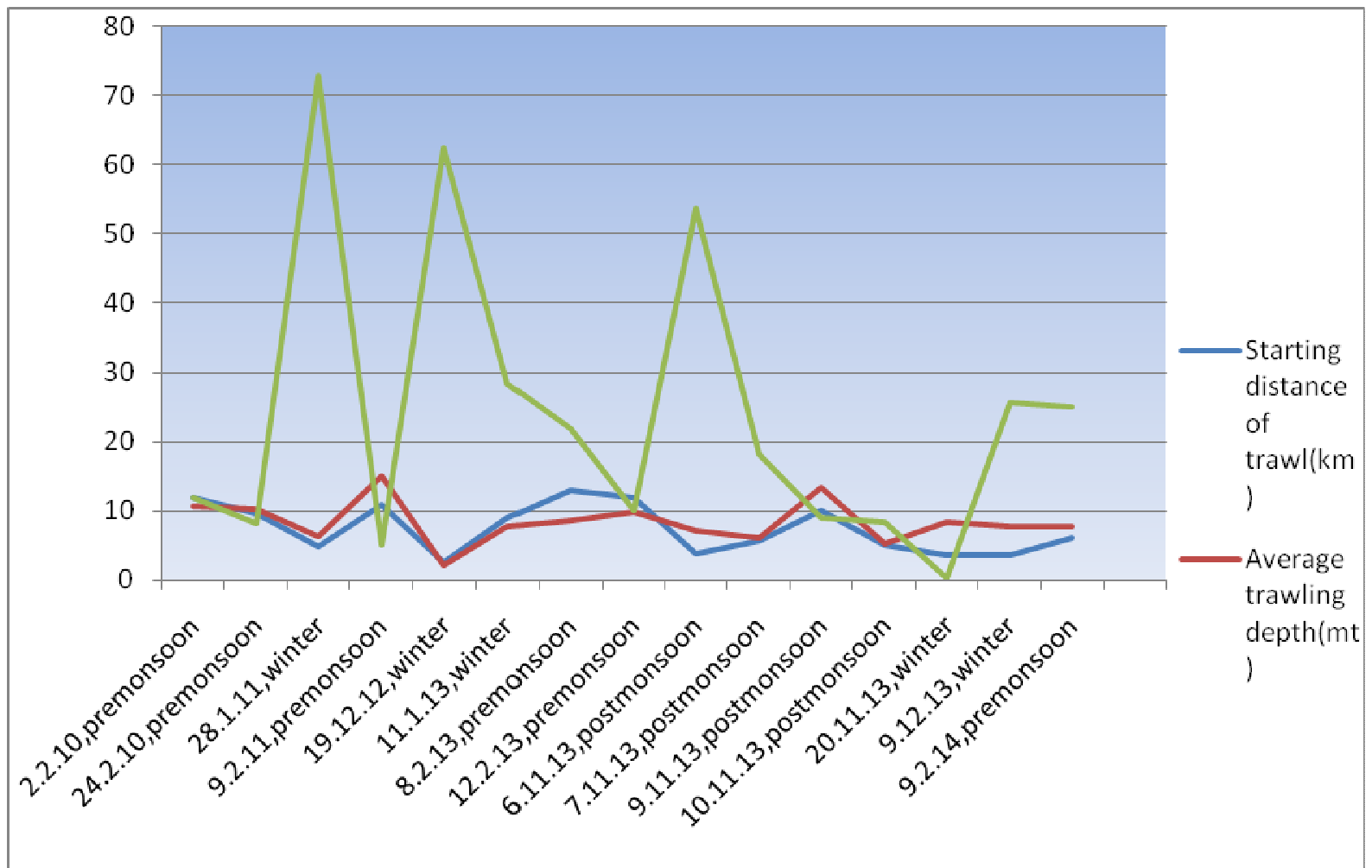

Fig.1 Seasonal marine biodiversity loss by trawling with 'distance' and 'depth' during 2010 - 2014

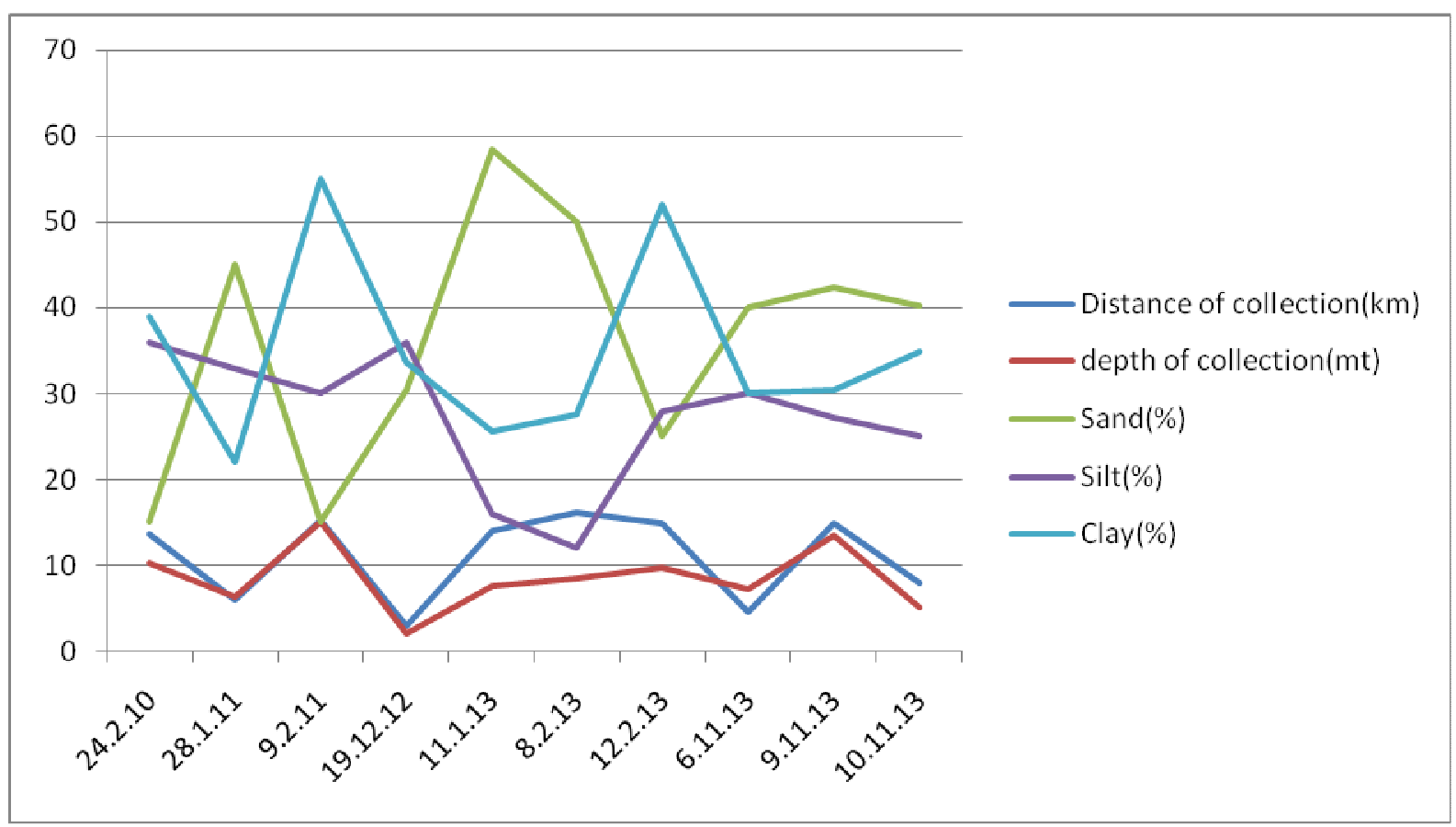

Fig.2 Changes in benthic sand, silt \& clay with 'distance' \& 'depth' during 2010 - 2013 


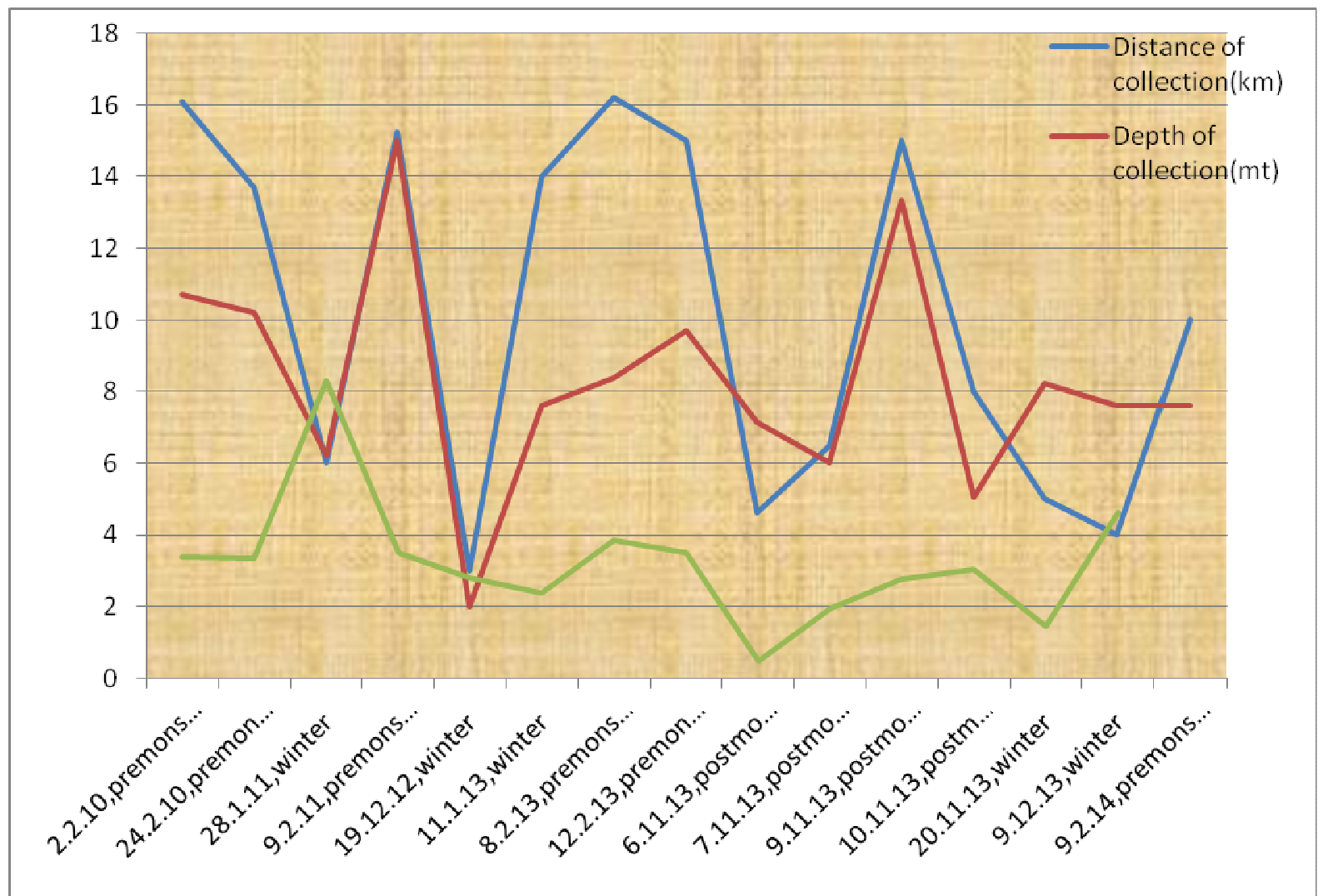

Fig.3. Changes in organic carbon in benthic soil with 'distance' \& 'depth' during $2010-2014$

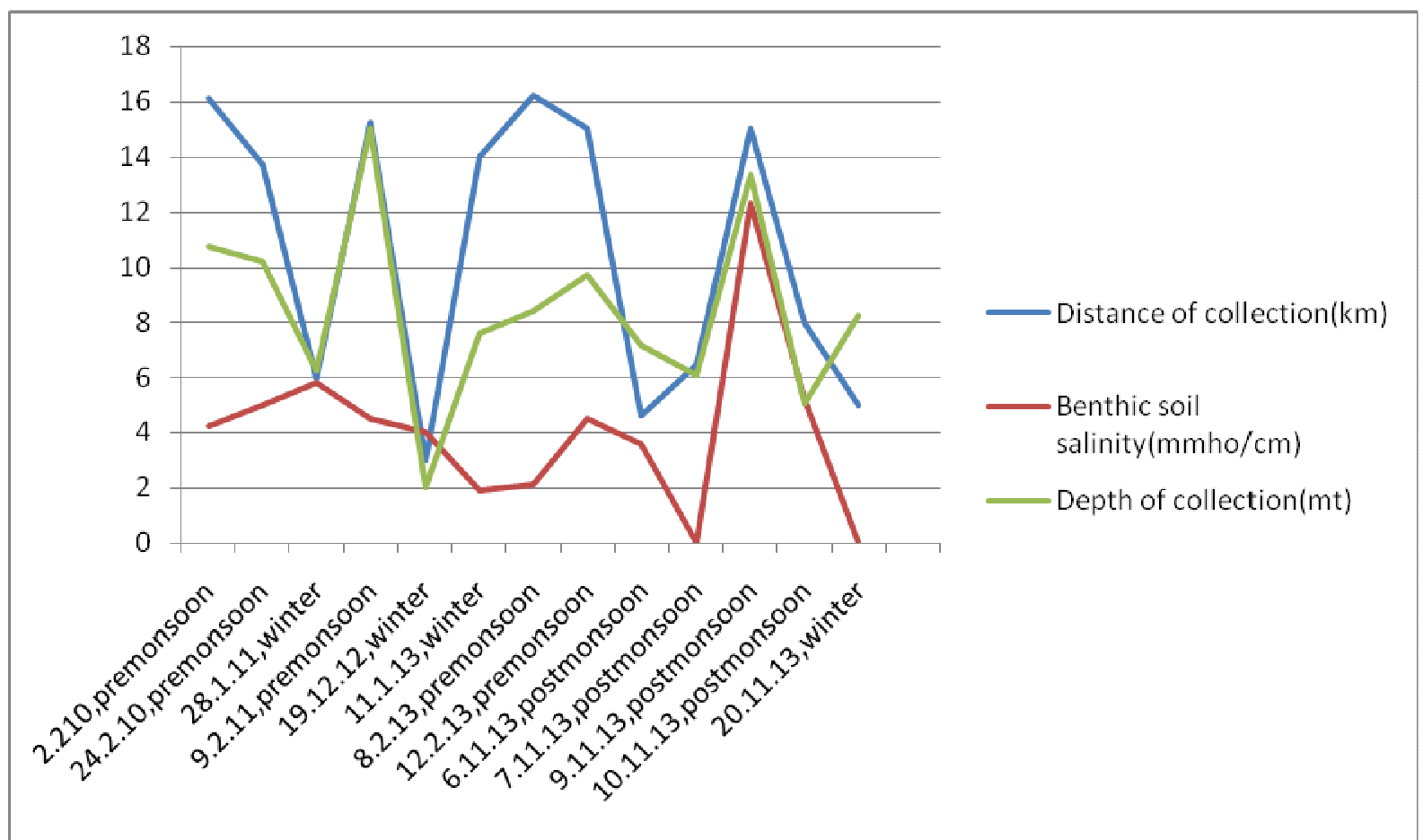

Fig.4 Seasonal changes in benthic soil salinity with ‘distance' \& 'depth'during 2010 - 2014 


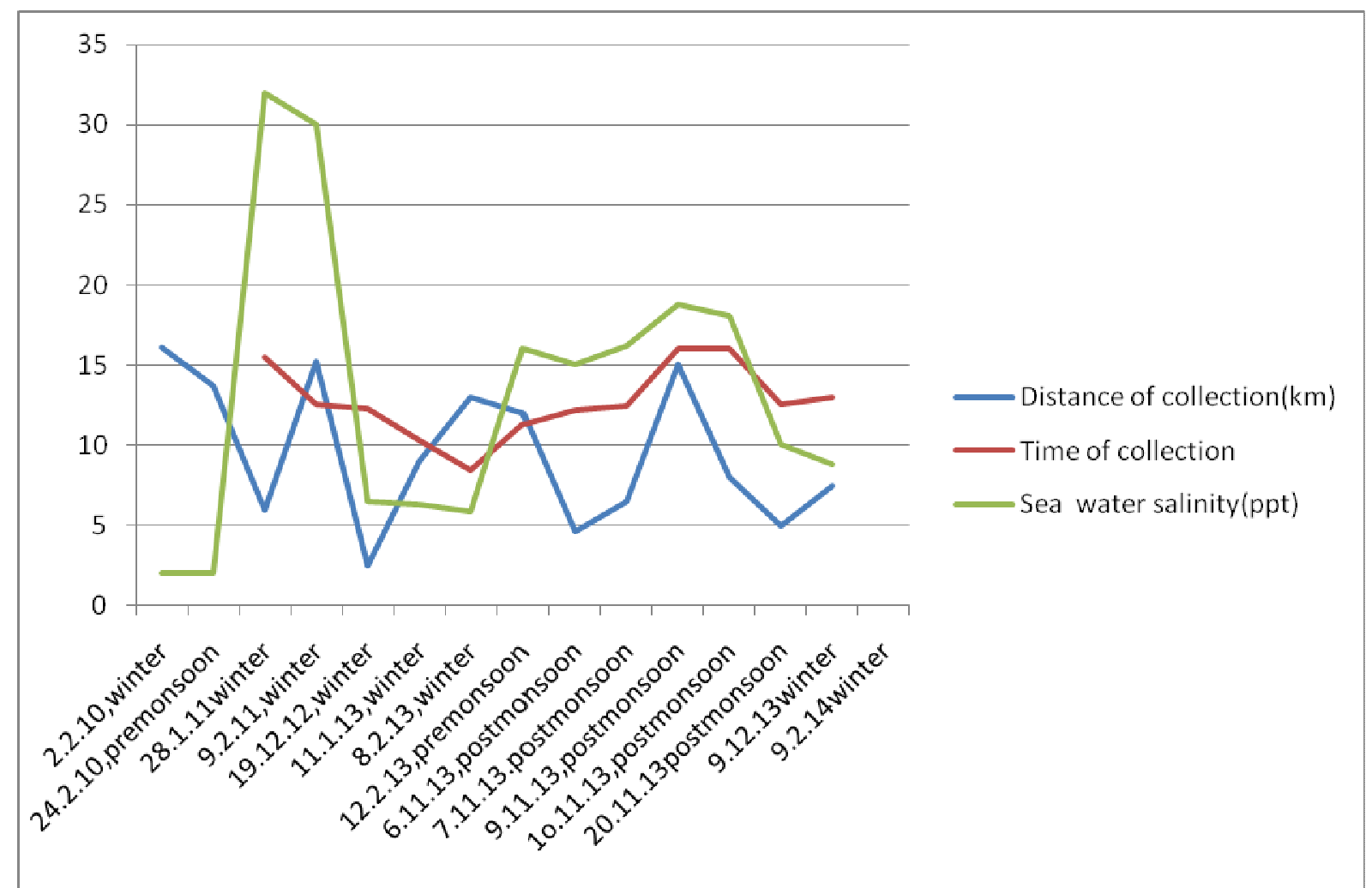

Fig.5 Seasonal changes in sea water salinity with 'distance' \& 'time' during 2010 - 2014

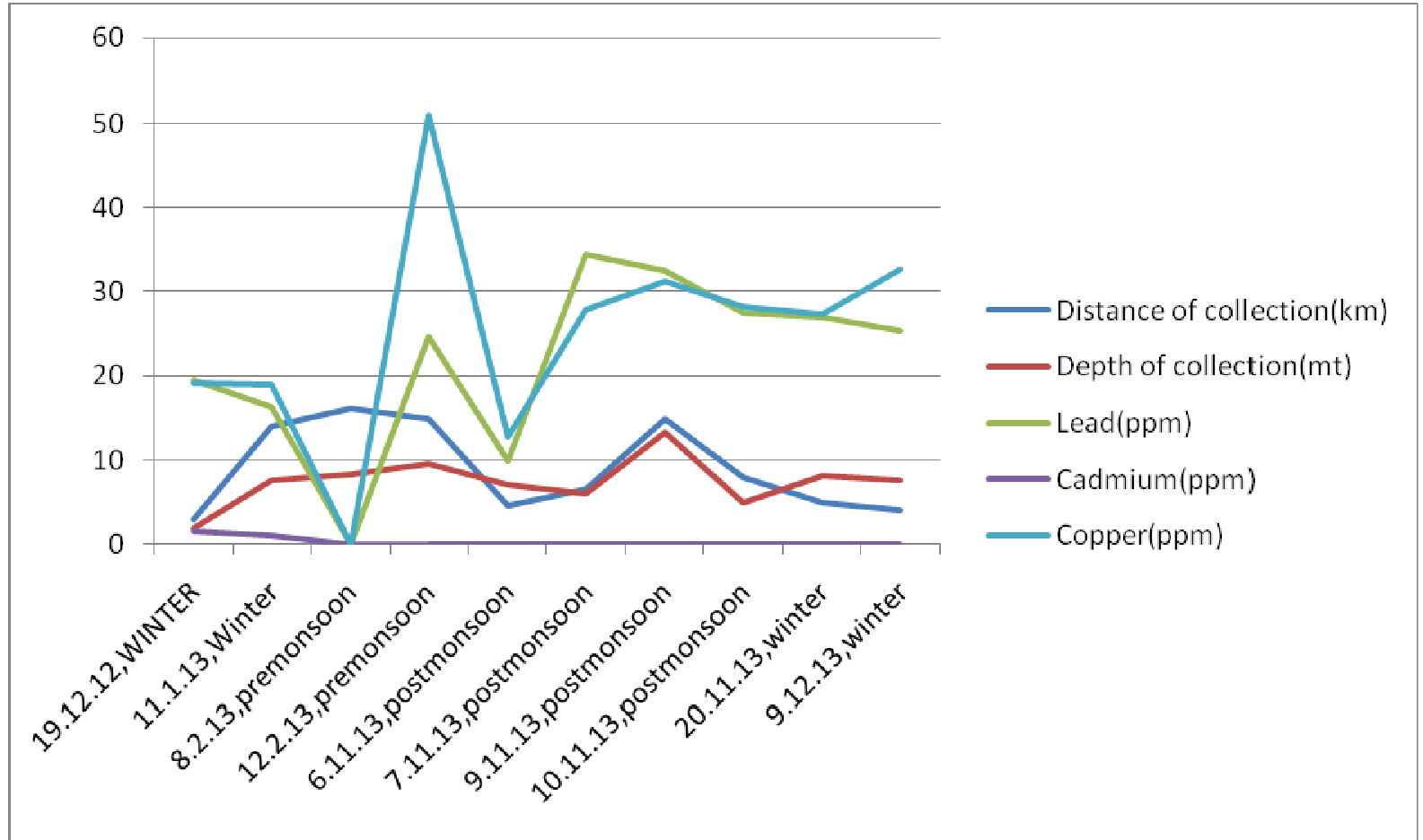

Fig.6 Changes in benthic soil pollutants with 'distance' \& 'depth' during $2010-2013$ 